\title{
A Proposed New Graduate Program in Technical Product Innovation at UBC
}

\author{
Antony J. Hodgson and H.F. Machiel Van der Loos \\ Department of Mechanical Engineering, University of British Columbia \\ ahodgson@mech.ubc.ca
}

\begin{abstract}
-
UBC has held two NSERC Chairs in Design Engineering through which we have established connections with the Sauder School of Business (through our New Venture Design program) and other engineering departments (through our multidisciplinary capstone design course). We are now planning a renewal application for our Design Chair that aims to extend the scope of designrelated work at UBC by establishing a graduate program in Technical Product Innovation (TPI) that will connect Applied Science, the Business School, Computer Science and Industrial Design at the Emily Carr University of Art and Design. The TPI program will offer both thesis and non-thesis degree options at the master's level, along with a concentration certificate that will be available to nonTPI students. The curriculum will have five key components: (1) a technical base in the area of the student's undergraduate specialization, (2) courses in innovation theory and entrepreneurship in collaboration with the Sauder School, (3) courses in human factors engineering in collaboration with computer science, (4) special 'passport-style' skills-based courses in prototyping, visual communication and user evaluation in collaboration with industrial design, and (5) project and thesis options that will allow for work on industry- or entrepreneurship-based design projects. The goal of the proposed program will be to train students to take on leadership roles in product development programs in both startups and established companies. The TPI program will initially focus on three key areas: medical technologies, consumer products and business-to-business products. It will build on two significant cross-university initiatives - the multi-faculty Human-Computer Interaction interest group (hci@ubc) and the universitywide Entrepreneurship@UBC program - and will tie into related emerging initiatives such as the Innovation Hub at Vancouver General Hospital and Wearables@UBC.
\end{abstract}

Keywords: Innovation, entrepreneurship, curriculum, design, technical products.

\section{INTRODUCTION}

Over the past few years, a number of influential reports have discussed the state of innovation in Canada ([1-3]), most of which agree that, although Canada performs well in research, it is a comparative underperformer in translating research findings into commercialized products and systems. While these reports have made numerous recommendations aimed at improving Canada's level of innovation, their focus has primarily been on business and very little on engineers and engineering. Since we engineers tend to think of ourselves as essential to creating innovative products, this lack of recognition and attention was striking to us, and we began considering how well our engineering curriculum actually develops individuals who pursue innovation in their post-training careers and started developing a proposal for a new curriculum in Technical Product Innovation (TPI).

In our thinking, we were inspired by the approach described by the renowned design firm IDEO's CEO Tim Brown, who argues that industry needs ' $\mathrm{T}$ '-shaped people - that is, people with significant depth in a particular skill area (the vertical bar of the T) and a 'disposition for collaboration' with others (the horizontal bar). Through a series of discussions with people in industry, we learned that many would value a graduate who had been thoroughly trained at the bachelor's level in a recognized engineering discipline (the vertical bar), but who then spent time in a graduate program acquiring the skills and experience needed to collaborate across disciplines. For example, a Chief Development Officer at a major international product design firm told us that "a compelling part of [your proposed] TPI program is that, as a master's program, the student candidates have already established a complete foundation in a discipline or craft. The TPI program [would then allow] them to grow from this strong base and build sensitivity and knowledge in the other important perspectives that influence product development."

The purpose of this paper, therefore, is to describe a graduate curriculum proposal we have been developing as the basis for an upcoming application for an NSERC Chair in Design Engineering at UBC (following the 
wrapping up this year of our current chair focused on multidisciplinary and new venture design).

\section{LITERATURE REVIEW \& RELATED PROGRAMS}

What should a curriculum in Technical Product Innovation contain, and how should it be structured? The BC Premier's Technology Council published a report in 2008 ("The Industrial Design Advantage" [4]) in which they noted that a 7-year study of 200 companies in the US manufacturing sector showed that companies that used effective industrial design practices had an earnings to net sales ratio that was on average $75 \%$ higher than the industry average over the seven years. Given the strong link between product-focused design and development and commercial success, we believe that it is crucial to explicitly train engineers in state-of-the-art product design processes - solid training in conventional engineering skills alone is no longer sufficient. As Nono Ohga, Chairman and CEO of Sony, said: "we assume all products of our competitors will have basically the same technology, price, performance and features. Design [ie, careful attention to user experience issues] is the only thing that differentiates one product from another in the market place!" ([5] - elaboration ours). Anderson recently outlined a series of courses at the undergraduate level focusing on Strategies for Innovation, Design Skills and Innovation Projects [6].

We also realized that there is considerable value in explicitly training students to launch new enterprises. As Åstebro et al [7] recently reported, startups arising from recently-graduated science and engineering students are at least ten times more numerous than those arising from faculty members. Furthermore, while most existing innovation support programs specifically target existing companies (eg, the NSERC Collaborative R\&D program), relatively little attention is paid to launching new enterprises. In some domains (eg, medical technologies, or medtech), this is the dominant mode of innovation large multinational firms wait for emerging firms to demonstrate strong early value and then acquire the small firms once their technology has been 'derisked'. A training program in Technical Product Innovation must take explicit account of this dynamic.

This emphasis on the importance of entrepreneurship education is echoed in the 2012 UK Royal Academy of Engineers' report [8] entitled "Educating engineers to drive the innovation economy" in which they state that "crossdisciplinary masters programmes in conjunction with entrepreneurial boot camps are shown to be effective models for engineering researchers to learn how best to commercialise novel research."

Many universities have, of course, developed courses and programs that address one or more aspects of innovation that we can draw on for inspiration. However, the majority of graduate programs in innovation or entrepreneurship are based in schools of business (eg, the University of Waterloo's Master of Business, Entrepreneurship and Technology program) - there are relatively few that are specifically focused on technical product innovation aimed at engineers and based in schools of engineering.

In Canada, perhaps the most well-established program that is jointly offered by engineering and business is McMaster University's Master's program in Engineering Entrepreneurship and Innovation (MEEI), which consists of a five course sequence in entrepreneurship and innovation processes, some advanced engineering work, and a mentored 'enterprise project' in which students seek to launch a company based on ideas arising from several sources: faculty research ideas, external private or public sector entities, or students' entrepreneurial ideas.

Carleton University offers a Technology Innovation Management (TIM) program in both MBE and MASc formats. There are three compulsory TIM courses, plus several management-focused TIM electives. The program is rounded out by additional courses from the existing engineering curriculum.

Beyond Canada, a number of similar programs exist (eg, the Master of Entrepreneurship degree at the University of Michigan). These programs focus on business-creation processes in technology-focused industries, but do not explicitly address the engineering side of new products.

One example of a program that does have more of an engineering focus is Carnegie Mellon University's master's program in Integrated Innovation for Products \& Services that offers courses in Design and Visual Processes, Industrial Design, Machine Shop Practice and User Evaluation Methods. Similarly, Lehigh University's Technical Entrepreneurship program offers explicit courses in Creativity; Visual Thinking; Prototyping, Modeling and Testing; and Integrated Product Development, in addition to courses in entrepreneurial processes. Stanford University offers what is arguably the most famous design-focused graduate program - a Masters of Science in Engineering Design degree that combines courses in design thinking, methodology, and strategy with a second year 'Design Garage' project.

Dartmouth University offers a $\mathrm{PhD}$ Innovation Program that offers up to three years of funding and associated training to enable a student to pursue an entrepreneurial idea emerging from the first two years of their doctoral work.

The Virginia Commonwealth University (VCU) Master of Product Innovation program offers a Product Innovation Bootcamp in the summer.

Chalmers University in Sweden has a unique master's program in entrepreneurship - students apply to work with 
a technology contributed by a faculty member (typically arising from their research) and faculty members select the students they wish to admit. In the 10 years from 1998 to 2007, this program (which accepts 20 students per year) created 32 firms employing a total of 220 people, and $43 \%$ of recent graduates have started one or more companies.

Other European universities with engineering-based product innovation programs include the Technical University of Delft, the University of Southern Denmark, and the Technical University of Denmark (typically a two-year program). Imperial College (London) has a particularly notable MSc degree in Innovation Design Engineering that links the School of Design at the Royal College of Art (RCA) and the School of Design Engineering at Imperial.

The Master Program of Innovation for Design and Engineering at the Advanced Institute of Industrial Technology in Tokyo likewise offers a program that links industrial design and engineering.

Perhaps the most relevant medtech-focused degree program is the non-thesis Master of Science in Engineering (MSE) in Bioengineering Innovation and Design at Johns Hopkins University - we propose to use some of the ideas from their curriculum to guide the design of a medtech stream within our TPI program.

\section{PROGRAM DESIGN}

We propose to target three main groups of potential students with the TPI program:

1. Students graduating from an undergraduate degree program in a conventional engineering discipline who wish to prepare themselves for a career in technical product development, whether through a design consultancy or in a firm developing technical products,

2. Students interested in learning how to launch new companies in technical domains, and

3. Practicing engineers interested in moving into leadership positions in companies developing technical products.

To address the needs of these students, we propose two masters degrees in Technical Product Innovation one to be offered in a one-year Master of Engineering Leadership (MEL) format (coursework + supervised project) and the other in a two-year Master of Applied Science format (less coursework and a more extended thesis project). Both programs will share the following structure:

- a technical base: advanced courses in the student's area of primary technical interest (enhancing the vertical bar of the ' $\mathrm{T}$ ')

- courses in three pillars (the horizontal bar):
○ human factors engineering, user experience design, ethnography

○ prototyping skills and evaluation processes

$\circ$ innovation theory and entrepreneurial practice

- an integrating project or thesis focused on technical product innovation

While both degree programs will consist of 30 credits, the mix of courses and credits will differ. The MEL program will be nominally 12-16 months in duration and will consist of 24 credits of coursework and a six credit project, while the MASc program will be nominally 24 months in duration and will consist of 18 credits of coursework and a 12 credit thesis. Moreover, the MEL program will conform to the general structure of the new suite of professional practice Master of Engineering Leadership programs being introduced at UBC. In particular, students in the MEL program will take a special 4.5 credit course in technical leadership and will have access to certain courses in the Sauder School of Business's MBA curriculum that will not be available to the MASc students.

The curricula for these two programs, showing similarities and differences, are outlined in Table 1 (credit values in parentheses).

A brief description of the courses listed above follows:

APPP $^{1} 501$ Project Management and Leadership, APPP 502 Leadership and Sustainability, APPP 503 Organizational Leadership and APPP 504 Business Acumen for Technical Leaders are the core courses offered as part of the new APSC Professional Program Platform; responsibility for design and instruction of these courses rests with a cross-faculty working group.

TPIN $^{2} 500$ Product Innovation and Management will be a new flagship course to be co-designed by the Design Chairs and the Sauder School of Business. It will be modeled on an existing 'bootcamp'-style course in Product Management, but customized to address the special issues associated with designing and developing technical products. It is possible that in a year or two we may be able to merge APPP 504 and TPIN 500 into a unified course that is taken by both MEL and MASc students, but at the moment, APPP 504 is already 'in the works'.

TPIN 520, 521 and 522 will be special 'passport'-style courses that will be co-designed by the Design Chairs and instructors at the Emily Carr University of Art and Design, with additional input from HCI-affiliated instructors at UBC. The goal of these courses will be to ensure that graduates of the TPI program will have a broad range of practical skills relevant to product design

\footnotetext{
${ }^{1}$ APPP $=$ APSC Professional Program Platform

${ }^{2} \mathrm{TPIN}=$ Technical Product INnovation program
} 
and development. Since students will enter the program from a range of backgrounds, each will already have significant skills in particular areas. To avoid students wasting time on skills they already possess, we will create a range of modules that can be taken in various formats and combinations to allow students to fill in the skills they most wish to acquire - students will earn a 'stamp' for each module they complete, and a certain number of stamps will be required to earn a course credit. The majority of these modules will be strongly hands-on in nature and will be offered in a workshop format at various facilities at both UBC and ECUAD. The prototyping skills modules will cover a range of mechanical, electrical and software-related skills - for example, we anticipate offering modules in working with waterjet and laser cutters, 3D printing technologies, molding techniques, microprocessor-based rapid prototyping systems (eg, Arduino and Beagle Bone), solid modeling programs, programming devices for internet connectivity, applied signal acquisition and processing techniques, etc. The conceptualization, visualization and visual communication course will offer students training in the various sketching, rendering and communication skills typically taught to industrial design students, while the user evaluation course will teach students various practical observational and interviewing techniques to assess usability of designs. Modules in these courses will be a minimum of 4 hours in duration, with typical lengths of 8-12 hours, and 40 hours of modules will be required to earn one course credit.

Note that most students who take the TPI curriculum will be able to customize their program relatively easily so that they also satisfy the requirements for the existing Human Computer Interaction (HCI) Subspecialization, which requires four courses in HCI, most of which can fit smoothly into the Human Factors and Visualization / Prototyping / User Evaluation categories of the TPI program.

Because one of our focus areas is in the area of medical technologies, we will also specify a stream for Medtech Product Innovation - this will follow the format above, but will specify particular courses in the Technical Base category and will offer special modules in the TPIN 520-522 courses. In addition, we may make special electives available in future in the Human Factors and Innovation and Entrepreneurship categories.

Extra-Faculty Interactions: Several of the courses in the curriculum described above will be open to students beyond Applied Science. In particular, we anticipate collaborations with the Sauder School of Business, the Department of Computer Science, and the Industrial Design program at Emily Carr University of Art and Design (the latter involving students at both the senior undergraduate and masters levels). In addition, we anticipate that many or most of the TPI students will participate in and benefit from two cross-faculty and cross-university programs: the Human-Computer Interaction interest group and the Entrepreneurship@UBC (e@ubc) program.

MEL Projects: The projects for the MEL students will nominally be four months in duration, and will take one of three primary forms:

- Industrial Placement - with a company that is developing a new technical product

- Consultancy Placement - with a design firm that offers services to multiple clients

- Entrepreneurial Project - a project proposed by the student or one of our partners

MASc Theses: The theses for the MASc students will nominally be 16 months in duration, will be supervised by faculty members who may or may not be one of the Chair applicants, and will take one of three primary forms:

- Partnered Product Development: A partnership with a company that is developing a new technical product (typically using funding programs such as the NSERC Industrial Postgraduate Fellowship, an Engage or MITACS grant, an Idea to Innovation grant, or a Collaborative Research and Development grant)

- Design Research: A design-focused research project (typically funded from regular grants of a faculty member or from the Design Chair funds)

- Entrepreneurial Thesis: An extended entrepreneurial project proposed by the student or one of our partners; this project would be tied into our entrepreneurship support programs and the student may work in a team supported by mentors and potentially by external investors. Sources for such projects could include projects disclosed to our University Industry Liaison Office, proposed by the students themselves, or brought to us by external partners.

Certificate Programs: In addition to the two masters degree programs envisioned above, we anticipate that students in existing degree programs, whether at the masters or doctoral level, or engineers currently not in a degree program, may wish to take some subset of the courses that would be offered through this program. We therefore propose to define a certificate or minor in Technical Product Innovation that could be taken either as an add-on to an existing degree or as a stand-alone certificate. Our model for this will be the existing graduate Engineering Management Sub-specialization, which consists of 12 credits in engineering management. Students enrolling for the certificate or minor will be required to take at least three course credits in each of the 
three pillar areas, and a total of 12 credits in these pillar areas altogether.

\section{DISCUSSION}

Overall, our proposed TPI program is perhaps most similar to the Carnegie Mellon and Lehigh programs in that it will explicitly draw on engineering, business and industrial design. In addition, we will have direct involvement from computer science in the areas of user experience and interaction design, supported by the existing Human Computer Interaction group at UBC. Like Imperial College, we will have a direct association with an industrial design school. Like Virginia Commonwealth University, we will offer a bootcamptype experience in entrepreneurship. Like Chalmers University, we will offer students and faculty a mechanism for advancing research-based projects towards commercialization, and, like McMaster, we will offer students an opportunity to pursue their own technologybased entrepreneurial ventures while earning a master's degree. We believe that this program will be unique in Canada in integrating engineering, business, industrial design and computer science, in combination with offering an entrepreneurially-focused thesis or project.

\section{References}

[1] Review of Federal Support to Research and Development, Jenkins Report, 2011

[2] Innovation Report Card, Conference Board of Canada, 2012

[3] OECD Science, Technology and Innovation Outlook, 2012

[4] The Industrial Design Advantage, BC Premier's Technology Council, 2008

[5] The Value of Design Factfinder Report, UK Design Council, 2007

[6] Anderson GT. An Approach to Teaching Innovation Processes in Engineering. IEEE Interdisciplinary Engineering Design Education Conference, 2013

[7] Åstebro T, Bazzazian N, Braguinsky S, Startups by recent university graduates and their faculty: Implications for university entrepreneurship policy, Research Policy, 41(4), May 2012, pp 663-677

[8] Educating engineers to drive the innovation economy, UK Royal Academy of Engineering Report, 2012 
Table 1. Overview of proposed TPI curriculum (credit value in parentheses; $3 \mathrm{cr}=3 \mathrm{~h}$ of classtime per week for one term).

\begin{tabular}{|c|c|c|}
\hline Components & MEL in TPI & MASc in TPI \\
\hline Technical Base & \multicolumn{2}{|c|}{$\begin{array}{l}\text { Technical Foundation in area of student's primary technical interest - selected } \\
\text { from existing APSC and related courses (6) }\end{array}$} \\
\hline Leadership (MEL only) & $\begin{array}{l}\text { APPP 501, 502, } 503 \text { - Leadership } \\
(4.5)\end{array}$ & $\mathrm{n} / \mathrm{a}$ \\
\hline $\begin{array}{l}\text { Innovation \& } \\
\text { Entrepreneurship (partnership } \\
\text { with Sauder) }\end{array}$ & $\begin{array}{l}\text { APPP } 504 \text { - Business Acumen }(3+) \\
\text { - restricted to MEL students }\end{array}$ & $\begin{array}{l}\text { TPIN } 500 \text { - Product Innovation and } \\
\text { Management }(4.5+)\end{array}$ \\
\hline \multirow[t]{2}{*}{$\begin{array}{l}\text { Human Factors Engineering } \\
\text { (partnership with UBC } \\
\text { Computer Science) }\end{array}$} & \multicolumn{2}{|c|}{$\begin{array}{l}\text { Select from: } \\
\text { - CPSC } 543 \text { Physical User Interface Design (3) } \\
\text { - } \text { CPSC } 544 \text { Human Computer Interaction (3) } \\
\text { - } \text { EECE } 518 \text { Human Interface Technologies (3) } \\
\text { - } \quad \text { PSYC 546A: Introduction to Graduate Statistics or similar } \\
\text { - } \quad \text { SPPerimental methods course (3) } 565 \text { Ergonomics (3) }\end{array}$} \\
\hline & $(6+)$ & $(3+)$ \\
\hline \multirow[t]{2}{*}{$\begin{array}{l}\text { Industrial Design: } \\
\text { Visualization, Prototyping and } \\
\text { User Evaluation Skills } \\
\text { (partnership with Emily Carr } \\
\text { Industrial Design) }\end{array}$} & \multicolumn{2}{|c|}{$\begin{array}{l}\text { Select from: } \\
\text { - } \\
\text { TPIN } 520 \text { Conceptualization, Rapid Visualization and Visual } \\
\text { - Communication (1-3) } \\
\text { - TPIN } 521 \text { Prototyping Techniques (1-3) } \\
\text { TPIN } 522 \text { User Evaluation (1-3) }\end{array}$} \\
\hline & $(3+)$ & $(3+)$ \\
\hline Integrating Project/Thesis & Project (6) & Thesis (12) \\
\hline Total Credits: & 30 (24 courses, 6 project) & 30 (18 courses, 12 thesis) \\
\hline
\end{tabular}

